\title{
Emisi metan dan fermentasi rumen in vitro dari ransum yang ditambahkan kitosan asal kulit udang
}

\author{
Rakhmad Perkasa Harahap ${ }^{1,3}$, Anuraga Jayanegara ${ }^{2, *}$, Nahrowi ${ }^{2}$, Sri Suharti ${ }^{2}$, Retno Budi \\ Lestari $^{1}$ \\ ${ }^{1}$ Program Studi Peternakan, Fakultas Pertanian, Universitas Tanjungpura, Pontianak, 78115 \\ ${ }^{2}$ Departemen Ilmu Nutrisi dan Teknologi Pakan, Fakultas Peternakan, IPB University, Bogor, 16680 \\ ${ }^{3}$ Program Studi Ilmu Nutrisi dan Pakan, Sekolah Pascasarjana, IPB University, Bogor, 16680 \\ *Correspondence: anuraga.jayanegara@gmail.com
}

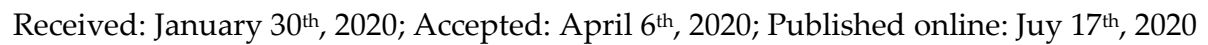

\section{Abstrak}

Tujuan: Penelitian ini dilakukan untuk mengevaluasi pengaruh penambahan kitosan asal kulit udang pada dosis yang berbeda ke dalam ransum basal terhadap emisi gas metan dan fermentasi rumen secara in vitro.

Metode: Perlakuan terdiri dari: P0 (ransum basal), P1 (ransum basal + kitosan 2\% BK), dan P2 (ransum basal + kitosan 4\% BK). Variabel yang diukur adalah kinetika produksi gas, produksi metan dinyatakan dalam produksi metan per unit bahan kering sampel dan produksi metan per unit bahan organik yang dicerna, kecernaan bahan kering (KCBK), kecernaan bahan organik (KCBO), volatile fatty acid (VFA), dan amonia $\left(\mathrm{NH}_{3}\right)$.

Hasil: Hasil penelitian menunjukkan bahwa penambahan kitosan 2\% dan 4\% BK dapat menurunkan secara signifikan $(\mathrm{P}<0,05)$ total produksi gas, laju produksi gas dan produksi metan. Namun demikian penambahan kitosan asal kulit udang pada tidak berbeda nyata terhadap peubah KCBK, KCBO, VFA, dan $\mathrm{NH}_{3}(\mathrm{P}>0,05)$.

Kesimpulan: Dapat disimpulkan bahwa kitosan dalam pakan bermanfaat dalam menurunkanemisi gas metan secara in vitro.

Kata Kunci: Metan; Kitosan; In vitro; Kulit udang

Abstract

Objective: This study was conducted to determine the effect of adding chitosan from shrimp waste at different doses into the basal ration on in vitro methane emission and rumen fermentation.

Methods: The treatments consisted of: P0 (basal ration), P1 (basal ration + chitosan 2\% DM), and P2 (basal ration + chitosan $4 \% \mathrm{DM}$ ). The variables measured were gas production kinetics, methane production expressed in methane production per unit of dry matter substrat and methane production per unit of digested organic matter, in vitro dry matter digestibility (IVDMD), in vitro organic matter digestibility (IVOMD), volatile fatty acids (VFA), and ammonia (NH3).

Results: The results showed that the addition of chitosan $2 \%$ and $4 \%$ DM significantly reduced $(\mathrm{P}<0,05)$ total gas production, gas production rate, and methane production. However, the addition of chitosan did not alter IVDMD, IVOMD, VFA, and $\mathrm{NH}_{3}$ variables $(\mathrm{P}>0,05)$.

Conclusions: It can be concluded that chitosan addition is useful for mitigating enteric methane emission in vitro. 
Keywords: Methane; Chitosan; In vitro; Shrimp waste.

\section{PENDAHULUAN}

Gas metan memiliki dampak gas rumah kaca lebih besar dibandingkan gas karbon dioksida. Produksi metan ternak ruminansia berasal dari sintesis selama fermentasi pakan dalam rumenyang memasok sekitar 5\% hingga 7\% dari gross energy pakan, sekitar 16 hingga $26 \mathrm{~g} / \mathrm{kg}$ pakan yang dikonsumsi [1]. Dengan demikian, pendekatan dengan cara penghambatan produksi $\mathrm{CH}_{4}$ pada ruminansia dianggap memberikan efisiensi pemanfaatan energi pakan, manfaat ekonomi dan mengurangi efek gas rumah kaca global [2]. Penghambatan produksi $\mathrm{CH}_{4}$ pada ruminansia dapat dilakukan dengan cara memanipulasi ekosistem rumen. Beberapa jenis senyawa alami yang memiliki sifat antimikroba dapat digunakan untuk memanipulasi ekosistem mikroba rumen.

Manipulasi ekosistem mikroba rumen untuk meningkatkan efisiensi penggunaan pakan dan mengurangi dampak lingkungan telah lama menjadi tujuan para peneliti nutrisi ternak ruminansia. Sejumlah aditif pakan asal kimia, antibiotik, metan inhibitor, agen defaunasi dan ekstrak dari tumbuhan telah terbukti meningkatkan metabolisme rumen dan pertumbuhan ternak ruminansia [3],[4]. Namun, kekhawatiran tentang keberadaan residu kimiawi dalam produk ternak, perkembangan resistensi bakteri terhadap antibiotik, dan toksisitas yang berlebihan serta biaya beberapa ekstrak tumbuhan telah membatasi penggunaannya dalam ransum pakan ternak ruminansia [5]. Sebagai akibatnya, para peneliti nutrisi ruminansia masih aktif mencari aditif pakan alternatif yang dapat meningkatkan fungsi rumen. Salah satu jenis senyawa alami yang memiliki sifat antimikroba dan berpotensi digunakan untuk memanipulasi ekosistem mikroba rumen adalah kitosan.

Kitosan adalah biopolimer yang dapat diperoleh dalam eksoskeleton dari kepiting dan udang. Kitosan sangat menarik untuk diteliti karena dapat mengubah profil volatil fatty acid (VFA) dan mengubah fermentasi rumen, serta meningkatkan konsentrasi propionat $\left(\mathrm{C}_{3}\right)$, sehingga mengurangi produksi $\mathrm{CH}_{4}$ [6]. Lebih lanjut, reduksi $\mathrm{CH}_{4}$ bisa disebabkan oleh derajat deasetilasi yang ditemukan dalam kitosan, yang dapat memodifikasi permeabilitas dinding sel bakteri metanogen [7]. Penelitian sebelumnya menunjukkan bahwa penambahan kitosan dapat menghambat sintesis $\mathrm{CH}_{4}$ in vitro ketika ditambahkan ke substratpada konsentrasi tinggi [8]. Selanjutnya, penambahan kitosan yang berasal dari serangga lalat tentara hitam (black soldier fly) pada konsentrasi 2\% substrat menghasilkan efek reduksi yang kuat terhadap emisi $\mathrm{CH}_{4}$ [6]. Penelitian ini bertujuan untuk mengetahui pengaruh penambahan kitosan yang berasal dari kulit udang pada konsentrasi berbeda padaransum ternak ruminansia terhadap produksi metan dan fermentasi rumen secara in vitro.

\section{MATERI DAN METODE}

\section{Persiapan sampel}

Aditif pakan yang digunakan adalah kitosan asal kulit udang (derajat deasetilasi 87,5\%; viskositas 50 cps; pH 7,1; kelarutan 99\%). Ransum basal (berdasarkan BK) terdiri dari $6,0 \%$ onggok, $10,0 \%$ dedak padi, $13,0 \%$ pollard, 4,0\% bungkil kedelai, 25,0\% bungkil sawit, 12,0\% bungkil kelapa, 5,0\% molases, 1,0\% garam, 1,5\% $\mathrm{CaCO}_{3}, 20,0 \%$ kulit kopi, dan 2,5\% ampas teh. Kandungan nutrisi ransum basal ditunjukkan pada Tabel 1, komposisi kimia dianalisis sesuai metode AOAC secara duplo [9]. Ransum basal diformulasikan untuk memenuhi kebutuhan energi dan protein domba lokal Indonesia [10].

\section{Uji fermentasi rumen dan kecernaan secara in vitro}

Pada penelitian ini penggunaan bagian cair dan partikel padat dari rumen diperoleh dari dua sapi fistula persilangan Ongole sebelum makan pagi di Pusat Penelitian Bioteknologi, Lembaga Ilmu Pengetahuan dan Penelitian Indonesia (LIPI), Cibinong, Bogor, Indonesia. Persetujuan penelitian diberikan dari Fakultas Peternakan, IPB University, Bogor, Indonesia. 
Sampel percobaan yang dievaluasi untuk fermentasi rumen in vitro dan pengujian kecernaan dengan mengikuti prosedur Theodorou et al. [11]. Sejumlah $0,75 \mathrm{~g}$ sampel dicampur dengan $75 \mathrm{ml}$ cairan rumen yang telah disaring dan buffer McDougall (cairan rumen : buffer $1: 4 \mathrm{v} / \mathrm{v}$ ) dalam botol scott 125 ml. Media inkubasi dan botol scott dialirkan dengan gas karbon dioksida untuk memastikan kondisi anaerob sebelum inkubasi dimulai. Botol scott segera ditutup dengan sumbat karet butyl dan disegel dengan penutup botol aluminium kemudian proses inkubasi dimulai. Untuk penentuan kinetika produksi gas in vitro, botol scott pertama berupa substrat sampel percobaan diinkubasi selama 24 jam dalam waterbath pada suhu konstan $39{ }^{\circ} \mathrm{C}$. Produksi gas dikeluarkan dan dicatat pada 2, 4, 6, 8, 10, 12, dan 24 jam setelah inkubasi menggunakan syringe $100 \mathrm{~mL}$ yang dilengkapi dengan jarum. Kinetika produksi gas diperoleh melalui persamaan eksponensial yang digagas oleh Orskov dan McDonald (1979) [12] berikut:

$$
\mathrm{p}=\mathrm{a}+\mathrm{b}\left(1-\mathrm{e}^{-\mathrm{ct}}\right)
$$

dengan $p$ adalah produksi gas kumulatif pada waktu $\mathrm{t}$ jam, sedangkan $\mathrm{a}, \mathrm{b}$ dan $\mathrm{c}$ merupakan konstanta dari persamaan eksponensial tersebut. Konstanta a, b dan c dapat diinterpretasikan sebagai produksi gas dari fraksi yang mudah larut (a), produksi gas dari fraksi yang tidak larut namun dapat difermentasikan (b) dan laju reaksi pembentukan gas (c). Dengan demikian $a+b$ dapat diartikan sebagai produksi gas maksimum yang dapat terbentuk selama proses fermentasi pada waktu $t$ mendekati tak terhingga [12]. Perhitungan dilakukan dengan persamaan regresi nonlinear menggunakan SPSS versi 20.

Pengambilan parameter produksi metan dilakukan setelah 24 jam inkubasi

Tabel 1. Komposisi dan kandungan nutrien ransum perlakuan

\begin{tabular}{|c|c|c|c|}
\hline \multirow{2}{*}{ Komponen } & \multicolumn{3}{|c|}{ Perlakuan } \\
\hline & P0 & P1 & P2 \\
\hline \multicolumn{4}{|l|}{ Bahan pakan (\% BK) } \\
\hline Onggok & 6 & 6 & 6 \\
\hline Dedak padi & 10 & 10 & 10 \\
\hline Pollard & 13 & 13 & 13 \\
\hline Bungkil kedelai & 4 & 4 & 4 \\
\hline Bungkil sawit & 25 & 25 & 25 \\
\hline Bungkil kelapa & 12 & 12 & 12 \\
\hline Molases & 5 & 5 & 5 \\
\hline Garam & 1 & 1 & 1 \\
\hline $\mathrm{CaCO}_{3}$ & 1,5 & 1,5 & 1,5 \\
\hline Kulit kopi & 20 & 20 & 20 \\
\hline Ampas teh & 2,5 & 2,5 & 2,5 \\
\hline Kitosan & 0 & 2 & 4 \\
\hline \multicolumn{4}{|l|}{ Komposisi kimia (\% BK) } \\
\hline Bahan kering (BK) & 87,3 & 94,4 & 91,2 \\
\hline Neutral-detergent fiber (NDF) & 59,9 & 61,4 & 61,1 \\
\hline Acid-detergent fiber (ADF) & 48,6 & 48,5 & 47,4 \\
\hline Protein kasar & 10,2 & 10,4 & 11,8 \\
\hline Lemak kasar & 6,3 & 6,5 & 6,9 \\
\hline Serat kasar & 6,7 & 8,3 & 8,5 \\
\hline Abu & 12,6 & 13,4 & 13,5 \\
\hline
\end{tabular}


menggunakan syringe yang dilengkapi dengan jarum dan dimasukkan kedalam botol yang telah disegel dan divakum. Konsentrasi metan diukur menggunakan Shimadzu 8A GC dengan flame ionization detector (FID). Untuk penentuan produk fermentasi, yaitu, total volatile fatty acid (VFA), amonia, dan kecernaan in vitro, botol scott kedua berupa substrat sampel percobaan diinkubasi dalam dua tahap selama $2 \times 24$ jam [13]. Setelah inkubasi 24 jam pertama, supernatan dikeluarkan dengan sentrifugasi untuk pengukuran total VFA dan amonia seperti yang dijelaskan dalam Jayanegara et al.(2016) [14]. Dalam inkubasi 24 jam kedua, residu selanjutnya diinkubasi dengan $75 \mathrm{ml}$ pepsin- $\mathrm{HCl} 0,2 \mathrm{~N}$ untuk penentuan kecernaan bahan kering in vitro (KCBK) dan kecernaan bahan organik in vitro (KCBO). Berat awal bahan kering (BK) dan bahan organik (BO) dikurangi dengan residu $\mathrm{BK}$ dan $\mathrm{BO}$ masing-masing untuk mendapatkan KCBK dan KCBO. Inkubasi in vitro dilakukan dalam 4 kali ulangan.

\section{Rancangan percobaan dan analisis data}

Percobaan yang dilakukan menggunakan rancangan acak kelompok (RAK) dengan 3 perlakuan dan 4 ulangan. Perlakuan terdiri dari: P0 (Ransum basal), P1 (Ransum basal $+2 \%$ BK kitosan), dan P2 (Ransum basal $+4 \%$ BK kitosan).
Pengelompokan perlakuan ke dalam unit-unit percobaan mengikuti rancangan acak kelompok (RAK), sehingga proses in vitro yang berbeda menjadi kelompok karena perbedaan variasi populasi dan aktivitas mikroba rumen dalam setiap waktu pengambilan sampel. Data outlier yang terdeteksi kemudian dihapus dari data set ketika skor Z lebih rendah dari -2 atau lebih tinggi dari 2. Data yang diperoleh dianalisis sidik ragam (ANOVA) pada taraf 5\%. Untuk perbandingan antar perlakuan yang berbeda mengunakan Duncan's multiple range test pada taraf 5\%. Analisis data dilakukan dengan menggunakan software IBM SPSS Statistics versi 20.

\section{HASIL DAN PEMBAHASAN}

\section{Kinetika produksi gas dan emisi metan}

Kurva produksi gas in vitro selama 24 jam waktu inkubasi ditunjukkan pada Gambar 1. Produksi gas pada P0, P1, dan P2 meningkat seiring dengan bertambahnya waktu inkubasi. Kurva produksi gas pada P1 lebih rendah dibandingkan dengan P0 (kontrol), yang berarti bahwa pemberian kitosan 2\% BK dapat mengurangi produksi gas. Kurva produksi gas P2 lebih rendah dibandingkan dengan P1, yang berarti bahwa penambahan dosis kitosan berbanding lurus dengan penurunan produksi gas. Produksi

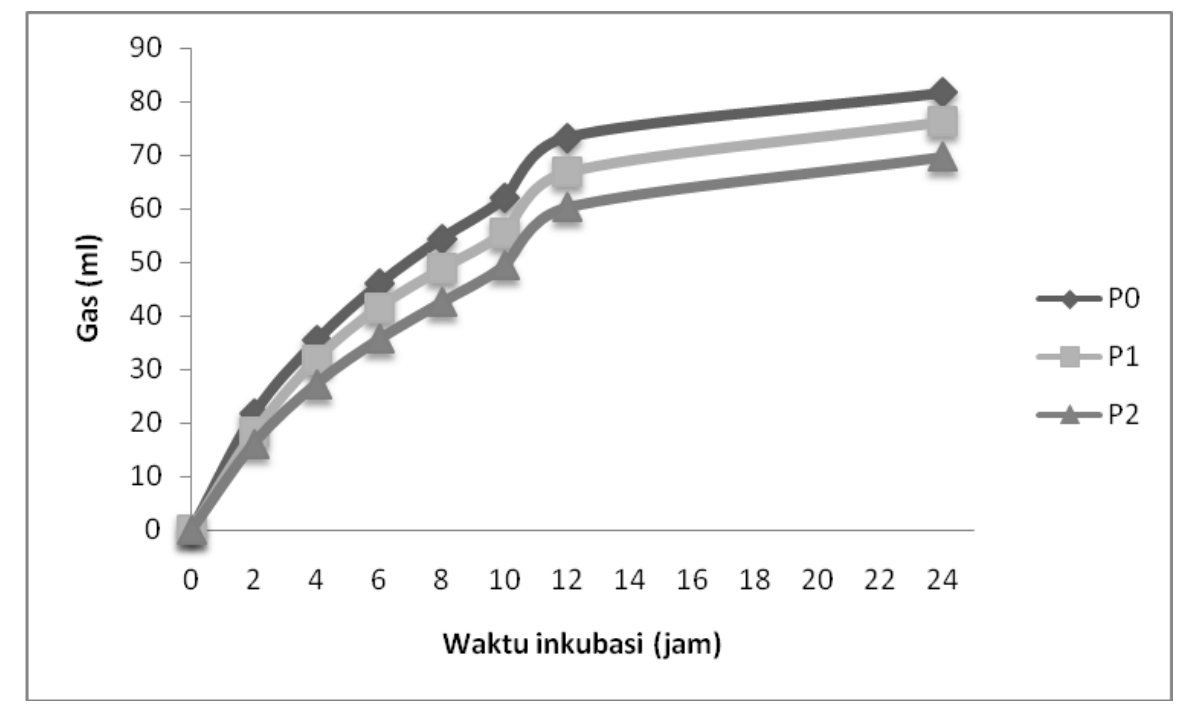

Gambar 1. Produksi gas kumulatif perlakuan P0 (- -), P1 (-m-), dan P2 (- $\mathbf{\Delta - )}$ selama 24 jam waktu inkubasi. P0, ransum basal (kontrol); P1, ransum basal + 2\% BK kitosan kulit udang; P2, ransum basal $+4 \%$ BK kitosan kulit udang 
gas yang dihasilkan pada metode ini berasal dari proses fermentasi rumen. Volatil fatty acid (VFA), karbon dioksida $\left(\mathrm{CO}_{2}\right)$ dan molekul $\mathrm{H}$ $\left(\mathrm{H}_{2}\right)$ diproduksi selama fermentasi karbohidrat oleh bakteri, protozoa dan jamur di rumen. VFA berfungsi sebagai sumber energi utama bagi ternak ruminansia [15]. Laju produksi gasin vitro setiap perlakuan semakin berkurang seiring dengan bertambahnya waktu inkubasi yang disebabkan semakin berkurangnya jumlah substrat yang dapat difermentasi. Korelasi positif antara waktu inkubasi dan produksi gas in vitro terkait dengan degradasi sampel pakan yang diinkubasi selama waktu inkubasi yang lebih lama [16].

Persamaan eksponensial Orskov dan McDonald (1979) [12] digunakan pada percobaan ini terdiri dari produksi gas total selama inkubasi 24 jam serta koefisien kinetika produksi gas yakni produksi gas maksimum $(\mathrm{a}+\mathrm{b})$ dan laju produksi gas $(\mathrm{c})$ yang ditunjukkan pada Tabel 2. Penambahan kitosan pada ransum basal menurunkan produksi total gas secara nyata pada waktu inkubasi 24 jam $(\mathrm{P}<0,05)$, yaitu secara berturut $\mathrm{P} 2<\mathrm{P} 1<\mathrm{P} 0$. Laju produksi gas (koefisien $\mathrm{c}$ ) pada P1 dan P2 lebih kecil dibandingkan P0 $(\mathrm{P}<0,05)$. Produksi gas maksimum (koefisien a + b) berbeda nyata $(\mathrm{P}<0,05)$, yaitu P2 menghasilkan produksi gas maksimum terendah, sedangkan P0 menghasilkan produksi gas tertinggi. Penambahan kitosan dapat menurunkan produksi gas melalui mekanisme perubahan ekosistem mikroorganisme rumen. Kitosan memiliki aktivitas antimikroba untuk melawan berbagai kelompok mikroorganisme rumen yang menghasilkan enzim untuk menghidrolisis pakan yang mengakibatkan pengurangan hasil produksi gas [17].

Data produksi metan perlakuan terdapat pada Tabel 2. Peubah metan yang ditampilkan pada penelitian ini yaitu produksi metan per unit sampel dan produksi metan per unit bahan organik tercerna. Produksi metan pada setiap perlakuan berbeda nyata $(\mathrm{P}<0,05)$. Produksi metan menurun dengan penambahan kitosan dalam ransum basal yang diuji pada setiap peubah produksi metan per unit sampel dan produksi metan per unit bahan organik tercerna. Produksi metan per unit sampel menurun dengan penambahan kitosan $2 \%$ BK dan $4 \%$ BK $(\mathrm{P}<0,05)$. Produksi metan per unit sampel menurun secara berurutan yaitu $\mathrm{P} 2<\mathrm{P} 1<\mathrm{P} 0$. Penambahan kitosan 2\% BK menunjukkan produksi metan per unit bahan organik tercerna menurun 15,49\%, sedangkan penambahan kitosan 4\% BK menunjukkan produksi metan per unit bahan organik tercerna menurun $19,76 \%$ dibandingkan ransum basal tanpa penambahan kitosan $(\mathrm{P}<0,05)$. Hal ini sesuai dengan penelitian sebelumnya yang menyatakan bahwa penambahan kitosan dapat menurunkan metan [18]. Penurunan produksi metan dengan penambahan kitosan dapat disebabkan melalui mekanisme penghambatan $\mathrm{H}_{2}$ sebagai substrat

Tabel 2. Kinetika produksi gas dan emisi metan $\left(\mathrm{CH}_{4}\right)$ ransum basal yang mengandung kitosan asal kulit udang

\begin{tabular}{llcccc}
\hline \multirow{2}{*}{ Peubah } & & \multicolumn{3}{c}{ Perlakuan } & SEM \\
\cline { 3 - 5 } & & P0 & P1 & P2 & 1,146 \\
\hline Gas24jam & $(\mathrm{ml})$ & $81,6^{\mathrm{a}}$ & $76,3^{\mathrm{b}}$ & $69,8^{\mathrm{c}}$ & 1,412 \\
$\mathrm{a}+\mathrm{b}$ & $(\mathrm{ml})$ & $86,6^{\mathrm{a}}$ & $81,7^{\mathrm{b}}$ & $76,4^{\mathrm{c}}$ & 0,004 \\
$\mathrm{c}$ & $(\mathrm{ml} / \mathrm{jam})$ & $0,131^{\mathrm{a}}$ & $0,122^{\mathrm{ab}}$ & $0,109^{\mathrm{b}}$ & 0,012 \\
$\mathrm{CH}_{4}$ & $(\mu \mathrm{l} / \mathrm{L}$ gas $)$ & $4,49^{\mathrm{a}}$ & $4,39^{\mathrm{b}}$ & $4,42^{\mathrm{b}}$ & 0,016 \\
$\mathrm{CH}_{4}$ & $(\mu \mathrm{l} / \mathrm{g}$ sampel $)$ & $0,915^{\mathrm{a}}$ & $0,806^{\mathrm{b}}$ & $0,754^{\mathrm{c}}$ & 0,025 \\
$\mathrm{CH}_{4} \mathrm{KCBO}$ & $(\mu \mathrm{l} / \mathrm{g} \mathrm{BO})$ & $1,194^{\mathrm{a}}$ & $1,009^{\mathrm{b}}$ & $0,958^{\mathrm{b}}$ & 0 \\
\hline
\end{tabular}

P0, ransum basal (kontrol); P1, ransum basal + 2\% BK kitosan kulit udang; P2, ransum basal + 4\% BK kitosan kulit udang; $a+b$, produksi gas maksimum; c, laju produksi gas; $\mathrm{KCBO}$, kecernaan bahan organik; $\mathrm{BO}$, bahan organik.

$\mathrm{a}, \mathrm{b}, \mathrm{c}$ superskrip berbeda pada baris yang sama menunjukkan berbeda nyata $(\mathrm{P}<0,05)$. 
pembentukan $\mathrm{CH}_{4}$ di dalam rumen. Penghambatan $\mathrm{H}_{2}$ merupakan hasil dari penurunan aktivitas protozoa dan bakteri fibrolitik karena kitosan dilaporkan berpengaruh lebih dominan sebagai antimikroba terhadap protozoa dan bakteri fibrolitik [19]. Hal ini sesuai dengan penelitian sebelumnya yang menyatakan bahwa kitosan dapat menghambat pertumbuhan bakteri fibrolitik yang memproduksi $\mathrm{H}_{2}$ [20].

\section{Kecernaan dan karakteristik fermentasi rumen in vitro}

Data KCBK, KCBO, VFA, dan $\mathrm{NH}_{3}$ terdapat pada Tabel 3. Penambahan kitosan pada penelitian ini tidak berbeda nyata terhadap peubah KCBK dan $\mathrm{KCBO}$ secara in vitro. Hal ini tidak sesuai dengan penelitian sebelumnya yang melaporkan bahwa penambahan kitosan dapat meningkatkan kecernaan BK, protein kasar, dan NDF in vitro pada substrat silase keseluruhan tanaman kedelai [21]. Namun, penelitian lain melaporkan bahwa penambahan kitosan dapat menurunkan kecernaan BK dan kecernaan NDF in vitro dengan substrat hijauan yang tinggi [22]. Perbedaan ini dapat terjadi akibat perbedaan aktivitas mikroorganisme rumen dalam mendegradasi substrat. Kitosan dapat mempengaruhi bakteri melalui interaksi ionik antara gugus amino bermuatan positif kitosan dengan permukaan bakteri yang bermuatan negatif yang menghasilkan perubahan permeabilitas membran bakteri [23]. Kitosan juga dilaporkan dapat menghambat pertumbuhan mikroorganisme yang memproduksi enzim CMCase [24].
Peubah VFA tidak berbeda nyata pada setiap perlakuan. Hal ini sesuai dengan penelitian sebelumnya yang melaporkan bahwa penambahan kitosan tidak memberikan pengaruh yang signifikan terhadap total VFA, tetapi berpengaruh terhadap peningkatan proporsi molar propionat dan penurunan rasio acetat:propionat [25]. Profil fermentasi dengan penambahan kitosan berdampak pada produksi $\mathrm{H}_{2}$ yang dapat mendukung dalam konversi fermentasi karbohidrat dari produksi asetat $\left(C_{2}\right)$ ke propionate $\left(C_{3}\right)$ [26]. Penambahan kitosan dapat menigkatkan efisiensi penggunaan energi pada ruminansia. Propionat, asetat, dan butirat adalah produk utama dalam fermentasi rumen. VFA merupakan bagian dari energi yang penting untuk ternak ruminansia [25].

Penambahan kitosan 2\% BK dan 4\% BK meningkatkan kandungan protein kasar ransum (Tabel 1). Namun penambahan kitosan tidak mempengaruhi peubah $\mathrm{NH}_{3}$ pada setiap perlakuan. Kitosan tidak menghambat degradasi protein oleh bakteri proteolitik di rumen sesuai dengan penelitian sebelumnya yang menyatakan bahwa tidak ada pengaruh penambahan kitosan terhadap konsentrasi $\mathrm{NH}_{3}$ pada rumen in vitro batch culture [19]. Penelitian sebelumnya melaporkan bahwa kitosan dapat meningkatkan kandungan $\mathrm{NH}_{3}$ pada fermentasi rumen dengan menggunakan substrat silase seluruh tanaman kedelai [27]. Peningkatan kandungan $\mathrm{NH}_{3}$ dapat juga disebabkan oleh peningkatan kandungan protein kasar yang dapat digunakan sebagai sumber nitrogen untuk ruminansia [28], [29]. Selain itu, unit glukosamin $\left(-\mathrm{NH}_{2}\right)$ kitosan

Tabel 3. Kecernaan ransum perlakuan kitosan kulit udang dan karakteristik fermentasi rumen

\begin{tabular}{llcccc}
\hline \multirow{2}{*}{ Peubah } & & \multicolumn{3}{c}{ Perlakuan } & \multirow{2}{*}{ SEM } \\
\cline { 3 - 5 } & & P0 & P1 & P2 & 0,393 \\
KCBK & $(\%)$ & 53,2 & 55,3 & 54,3 & 0,654 \\
KCBO & $(\%)$ & 54,2 & 57,7 & 56,4 & 1,753 \\
VFA & $(\mathrm{mmol} / \mathrm{l})$ & 77,8 & 83,4 & 77,5 & 0,599 \\
$\mathrm{NH}_{3}$ & $(\mathrm{mmol} / \mathrm{l})$ & 15,8 & 16,1 & 16,2 & \\
\hline
\end{tabular}

P0, ransum basal (kontrol); P1, ransum basal $+2 \%$ BK kitosan kulit udang; P2, ransum basal $+4 \%$ BK kitosan kulit udang; KCBK, kecernaan bahan kering; $\mathrm{KCBO}$, kecernaan bahan organik; VFA, volatile fatty acid. 
diubah menjadi bentuk terprotonasi terlarut $\left(-\mathrm{NH}^{+}{ }_{3}\right)$ ketika kitosan hadir dalam larutan asam encer [30].

\section{KESIMPULAN}

Penambahan kitosan asal kulit udang pada dosis $2 \%$ dan $4 \%$ BK dapat mengurangi produksi gas pada waktu inkubasi 24 jam, laju pembentukan gas, dan produksi metan secara in vitro. Penambahan kitosan asal kulit udang pada dosis $2 \%$ BK dan $4 \%$ BK tidak menurunkan dan meningkatkan kecernaan bahan kering (KCBK) dan kecernaan bahan organik (KCBO) secara in vitro. Kitosan asal kulit udang pada dosis $2 \%$ BK dan $4 \%$ BK tidak menurunkan dan meningkatkan konsentrasi VFA dan $\mathrm{NH}_{3}$ di dalam rumen secara in vitro yang merupakan hasil fermentasi rumen.

\section{KONFLIK KEPENTINGAN}

Penulis menyatakan tidak ada konflik kepentingan dengan pihak manapun terkait materi yang ditulis dalam naskah ini.

\section{UCAPAN TERIMA KASIH}

Kami berterima kasih kepada Direktorat Jenderal Pendidikan Tinggi, Kementerian Pendidikan dan Kebudayaan Indonesia, karena memberikan hibah "World Class Research" kepada penulis yang bersangkutan, dan Southeast Asian Regional Center for Graduate Study and Research in Agriculture (SEARCA) karena menyediakan Beasiswa Penelitian PhD ke penulis pertama.

\section{DAFTAR PUSTAKA}

1. Hristov, A. N., T. Ott, J. Tricarico, A. Rotz, G. Waghorn, A. Adesogan, J. Dijkstra, F. Montes, J. Oh, and E. Kebreab. 2013. Mitigation of methane and nitrous oxide emissions from animal operations: III. A review of animal management mitigation options. J. Anim. Sci. 91:5095-5113. doi:10.2527/jas.2013-6585.

2. Kaharabata, S. K., P. H. Schuepp, and R.L Desjardins. 2015. Estimating methane emissions from dairy cattle housed in a barn and feedlot using an atmospheric tracer. Environ. Sci. Technol. 34:3296-3302. doi:10.1021/es990578c.

3. Patra, A. K. and J. Saxena. 2011. Exploitation of dietary tannins to improve rumen metabolism and ruminant nutrition. J. Sci. 91:24-37. doi:10.1002/jsfa.4152.

4. Jayanegara, A., K. A. Sarwono, M. Kondo, H. Matsui, M. Ridla, E. B. Laconi, and Nahrowi. 2018. Use of 3-nitrooxypropanol as feed additive for mitigating enteric methane emissions from ruminants: a meta-analysis. Ital. J. Anim. Sci. 17:650-656. doi:10.1080/1828051X.2017.1404945.

5. Wina, E., S. Muetzel, and K. Becker. 2005. The impact of saponins or saponin-containing plant materials on ruminant production - a review. J. Agric. Food Chem. 53:8093-8105. doi:10.1021/jf048053d.

6. Haryati, R. P., A. Jayanegara, E. B. Laconi, M. Ridla, and P. Suptijah. 2019. Evaluation of chitin and chitosan from insect as feed additives to mitigate ruminal methane emission. In: AIP Conf. Proc. 2120:040008.

7. Zanferari, F., T. H. A. Vendramini, M. F. Rentas, R. Gardinal, G. D. Calomeni, L. G. Mesquita, C. S. Takiya., and F. P. Rennó. 2018. Effects of chitosan and whole raw soybeans on ruminal fermentation and bacterial populations, and milk fatty acid profile in dairy cows. J. Dairy Sci. 101:10939-10952. doi:10.3168/jds.2018-14675.

8. Goiri, I., A. Garcia-Rodriguez, and L. Oregui. 2009. Effects of chitosans on in vitro rumen digestion and fermentation of maize silage. Anim. Feed Sci. Tech. 148:276-287.

doi:10.1016/j.anifeedsci.2008.04.007.

9. AOAC. 2005. Official methods of analysis. 18th ed. Assoc. Off. Anal. Chem., Maryland Gaithersburg, USA.

10. Jayanegara, A., M. Ridla, D. A. Astuti, K. G. Wiryawan, E. B. Laconi, and Nahrowi. 2017. Determination of energy and protein requirements of sheep in indonesia using a meta-analytical approach. Media Peternakan. 40:118-127. 
doi:10.5398/medpet.2017.40.2.118.

11. Theodorou, M. K., B. A. Williams, M. S. Dhanoa, A. B. McAllan, and J. France. 1994. A simple gas production method using a pressure transducer to determine the fermentation kinetics of ruminant feeds. Anim. Feed Sci. Tech. 48: 185-197. doi:10.1016/0377-8401(94)90171-6.

12. Orskov, E. R. and I. McDonald. 1979. The estimation of protein degradability in the rumen from incubation measurements weighted according to rate of passage. J. Agri. Sci. 92:499-503. doi:10.1017/S0021859600063048.

13. Tilley, J. M. A. and R. Terry. 1963. A two-stage technique for the in vitro digestion of forage crops. Grass Forage Sci. 18:104-111. doi:10.1111/j.1365-2494.1963.tb00335.x.

14. Jayanegara, A., S. P. Dewi, N. Laylli, E. B. Laconi, N. Nahrowi, and M. Ridla. 2016. Determination of cell wall protein from selected feedstuffs and its relationship with ruminal protein digestibility in vitro. Media Peternakan. 39:134-140. doi:10.5398/medpet.2016.39.2.134.

15. Vyas, D., S. McGinn, and S. Duval. 2016. Effects of sustained reduction of enteric methane emissions with dietary supplementation of 3-nitrooxypropanol on growth performance of growing and finishing beef cattle. J. Anim. Sci. 94:2024-2034. doi:10.2527/jas.2015-0268.

16. Maccarana, L., M. Cattani, F. Tagliapietra, S. Schiavon, L. Bailoni, and R. Mantovani. 2016. Methodological factors affecting gas and methane production during in vitro rumen fermentation evaluated by meta-analysis approach. J. Anim. Sci. Biotechno. 7:35. doi:10.1186/s40104-016-0094-8.

17. Goiri, I., L. M. Oregui, and A. Garcia-Rodriguez. 2009. Dose-respon effects of chitosans on in vitro rumen digestion and fermentation of mixtures differing in forage-to-concentrate ratios. Anim. Feed Sci. Tech. 151:215-227. doi:10.1016/j.anifeedsci.2009.01.016.

18. Goiri, I., L. M. Oregui, and A. Garcia-Rodriguez. 2010. Use of chitosans to modulate ruminal fermentation of a 50:50 forage-to-concentrate diet in sheep. J.
Anim. Sci. 88:749-755. doi:10.2527/jas.2009-2377.

19. Belanche, A., E. Ramos-Morales, and C. J. Newbold. 2016. In vitro screening of natural feed additives from crustaceans, diatoms, seaweeds and plant extracts to manipulate rumen fermentation. J. Sci. 9:3069-3078. doi:10.1002/jsfa.7481.

20.Wang, Y., T. McAllister, L. Rode, K. Beauchemin, and D. Morgavi. 2001. Effects on exogenous enzyme preparation on microbial protein synthesis, enzyme activity and attachment to feed in the Rumen Simulation Technique (RUSITEC). Br. J. Nutr. 85:325-332. doi:10.1079/bjn2000277.

21. Gandra, J.R., C. S. Takiya, T. A. Del Valle, E. R. Oliveira, R. H. T. B. de Goes, E. R. S. Gandra, J. D. O. Batista, and H. M. C. Araki. 2018. Soybean whole-plant ensiled with chitosan and lactic acid bacteria: Microorganism counts, fermentative profile, and total losses. J. Dairy Sci. 101:7871-7880. doi:10.3168/jds.2017-14268.

22. Wencelova, M., Z. Varadyova, K. Mihalikova, S. Kisidayova, and D. Jalc. 2014. Evaluating the effects of chitosan, plant oils, and different diets on rumen metabolism and protozoan population in sheep. Turk. J. Vet. Anim. Sci. 38:26-33. doi:10.3906/vet/1307-19.

23. Kong, M., X. G. Chen, K. Xing, and H. J. Park. 2010. Antimicrobial properties of chitosan and mode of action: a state of the art review. Int. J. Food Microbiol. 144:51-63. doi:10.1016/j.ijfoodmicro.2010.09.012.

24. Benhabiles, M. S., R. Salah, H. Lounici, N. Drouichie, M. F. A. Goosen, and N. Mameri. 2012. Antibacterial activity of chitin, chitosan and its oligomers prepared from shrimp shell waste. Food Hydrocoll. 29:48-56. doi:10.1016/j.foodhyd.2012.02.013.

25. Li, C., X. Zhao, Y. Cao, Y. Lei, C. Liu, H. Wang, and J. Yao. 2013. Effects of chitosan on in vitro ruminal fermentation in diets with different forage to concentrate ratios. J. Anim. Vet. Adv. 12:839-845. doi:10.36478/javaa.2013.839.845.

26. Seankamsorn, A., A. Cherdthong, and M. Wanapat. 2020. Combining crude glycerin 
with chitosan can manipulate in vitro ruminal efficiency and inhibit methane synthesis. Anim. 10:30. doi: 10.3390/ani10010037.

27. Gandra, J. E., C. S. Takiya, E. R. Oliveira, P.G. Paiva, R. H. T. B. Goes, R. S. Gandra, and H. M. C. Araki. 2016. Nutrient digestion, microbial protein synthesis, and blood metabolites of Jersey heifers fed chitosan and whole raw soybeans. Rev. Bras. Zootec. 43:130-137. doi:10.1590/S1806-92902016000300007.

28. Manni, L., O. Ghorbel-Bellaaj, K. Jellouli, L. Younes, and M. Nasri. 2010. Extraction and characterization of chitin, chitosan, and protein hydrolysates prepared from shrimp waste by treatment with crude protease from Bacillus cereus SV1. Appl. Biochem. Biotech. 162:345-357. doi:10.1007/s12010-009-8846-y.

29. Fadel El-seed, A. N. M. A., H. E. M. Kamel, J. Sekine, M. Hishinuma, and K. Hamana. 2013. Short communication: Chitin and chitosan as possible novel nitrogen sources. Can. J. Anim. Sci. 83:161-163. doi:10.4141/A02-063.

30. Goy, R. C., D. Britto, and O. C. G. Assis. 2009. A review of the antimicrobial activity of chitosan. Polímeros. 19:241-247. doi:10.1590/S0104-14282009000300013. 